Document downloaded from:

http://hdl.handle.net/10251/96723

This paper must be cited as:

Clemente-Ricolfe, J. (2017). Consumer perceptions of online banking in Spain using netnography: a positioning story. International Journal of Bank Marketing. 35(6):966-982. doi:10.1108/IJBM-08-2016-0113

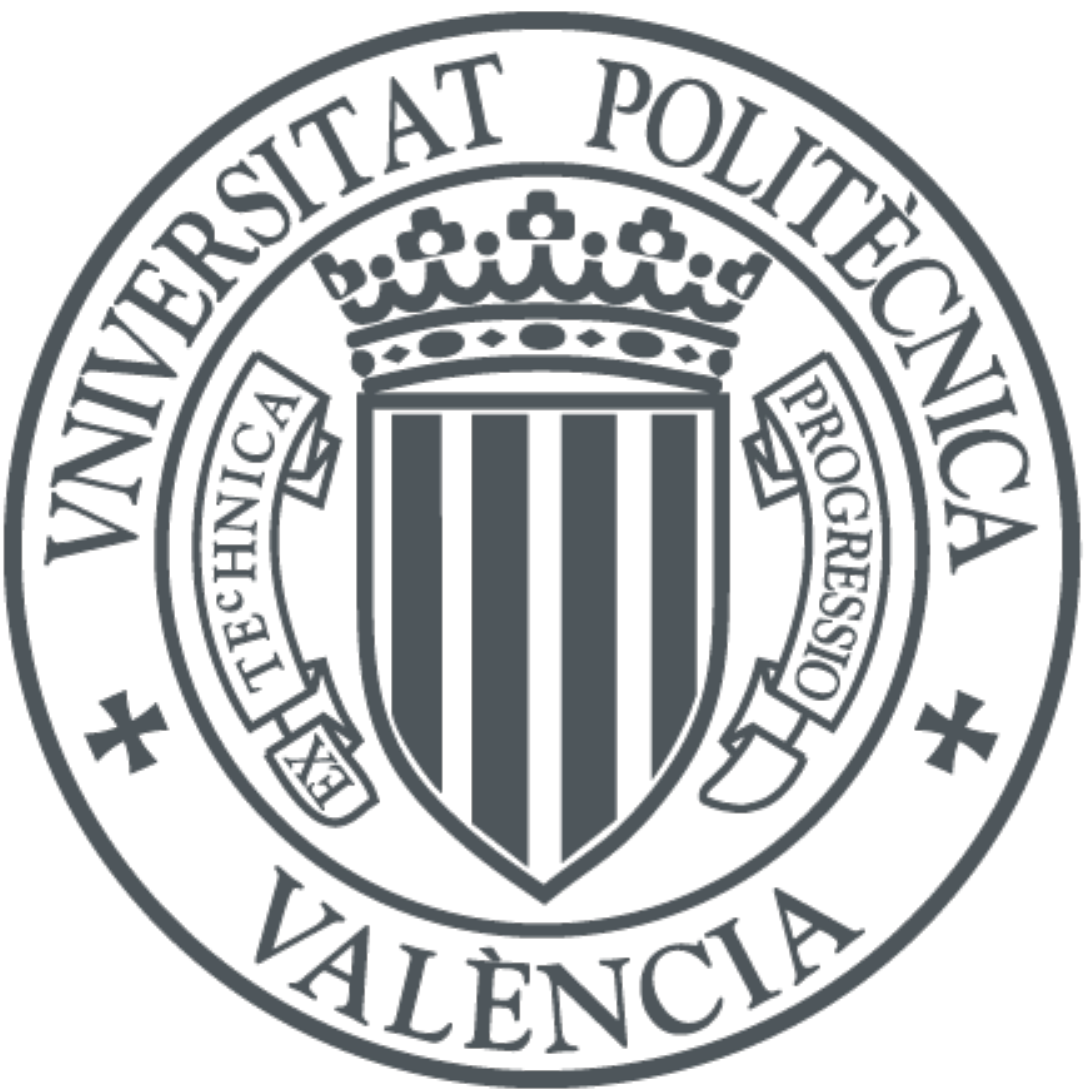

The final publication is available at

https://doi.org/10.1108//JBM-08-2016-0113

Copyright Emerald

Additional Information 


\title{
CONSUMER PERCEPTIONS OF ONLINE BANKING IN SPAIN USING NETNOGRAPHY: A POSITIONING STORY
}

\begin{abstract}
Today, a growing number of monetary transactions are carried out through online banking. This article applies netnography, a new technique for obtaining information, to determine the current positioning of online banking in Spain. The collection and analysis of 261 valid messages from two online consumer portals enables us to observe the existence of two competitor groups and two types of attributes. On the one hand, consumers perceive online banking as competitors depending on their size; and on the other hand, negative (or positive) aspects are compensated (or accepted) as a result of greater (or lesser) profitability. This means that different forms of value creation are offered with online banking clients. Furthermore, the methodology used represents an innovative way to determine the positioning of online banking and could be extended to other digital products.
\end{abstract}

Keywords: Consumer perception; Netnography; Digital consumer banking; Internet banking; Commercial banks

\section{Introduction}

Since the first online banking services based on the Internet were provided by Stanford Federal Credit Union (SFCU) in October 1994, online banking has spread rapidly in all countries of the world as a result of its convenience and ease in conducting transactions quickly and at a specific service level (Yoon, 2010). In effect, the incorporation of the Internet has transformed banking distribution in a direct way (Torres and VásquezPárraga, 2005). Internet banking or online banking is defined as the use of Internet as a remote delivery channel of banking system services via the World Wide Web (Nasri and Charfeddine, 2012).

This kind of banking benefits both financial entities as well as clients (Adesina and Ayo, 2010). Thus, online banks are not only able to provide information on their services, but also offer clients the opportunity to carry out interactive transactions (Aladwani, 2001). Moreover, online banks are replacing traditional services, thereby affecting clients' expectations (Uppal, 2008). Today, most traditional banks also offer their banking services to clients through the Internet. As a result, consumers are able to access their accounts, and to carry out transfers and other banking operations electronically through the bank's website at any time and from anywhere (Yoon and Barker Steege, 2013).

However, it is essential that both consumers and companies realise that despite the benefits of electronic transactions, they also have their inconveniences. For example, the growing interpersonal distance between banks and their clients may reduce confidence and increase security problems (Cai et al., 2008).

On the other hand, the growth of online banking users is constant (Tsai et al., 2013). One example would be Europe, where access to this service through tablets will increase from 19 million users in 2013, to 115 million users in 2018 (Forrester, 2014). In Spain, almost half the Internet population - 46\% - had used electronic banking during 
the last three months (Spain, 2014). In this context, it is essential to understand user behaviours and their perceived values of this service (Laukkanen, 2007).

The aim of this study is to determine the perceived positioning of the main online Banks in Spain through netnography. To do this, the paper proceeds as follows: first the current literature on consumer perceptions of online banking is reviewed, and netnography is identified as a source of information. The next section presents the research methodology used in the study. After this, the data is analysed, before closing the paper with a discussion of the data and the conclusions drawn.

\section{Literature review of consumer perceptions of online banking}

Current literature on online banking tends to focus on clients' perceptions of the advantages or disadvantages of this service and areas for improvement. The directories and databases of ScienceDirect, DOAJ and Google Scholar were used to compile Table I, which identifies the main attributes considered by consumers in the literature. According to this information, security was found to be a major factor influencing consumers' intentions to use e-banking services. Hoehle et al. (2012) define this as "consumer's perceptions of the uncertainty and adverse consequences of buying a product (or service)". For example, if a non-authorised person accesses a user's online banking account, this could result in considerable financial loss (Yoon and Barker Steege, 2013). Furthermore, if individuals view e-banking as secure, they will be more likely to use it (Hoehle et al, 2012). In other words, the lack of perceived security may reduce intentions to use the Internet for banking transactions (Tsai et al., 2013). Likewise, security problems contribute notably to decreases in client satisfaction (Bin Omar and et al., 2011).

Secondly, many authors also point out that convenience is an important aspect in users' perceptions of online banking (Hoehle et al, 2012). Thus, saving time or being able to access bank accounts from anywhere and at any time of day has a significant impact on online banking use (Cai et al., 2008). Convenience is therefore a key element in the use of online banking services. In effect, clients can view the status of their accounts and carry out operations at any time from home or from work, without having to go to the bank and without having to stand in queues.

The ease of use is another attribute frequently cited by consumers. In fact, if e-banking was not easy to use, consumers would opt not to manage their personal finances via electronic banking channels (Hoehle et al, 2012). Therefore, ease of use is an antecedent of customer satisfaction within online banking (Yoon, 2010). Mansumitrchai and AlMalkawi (2011) highlight that ease of use was the most important attribute explaining the adoption of online banking in Mexico. This study also indicates that perceptions of online banking as complex to use can reduce the chances of non-users adopting online banking.

Trust is also one of the most important attributes in clients' perceptions of the use of Internet banking (Mavri and Ioannou, 2006). This plays an important role in promoting clients' likelihood of using online banking and in developing positive attitudes to this channel (Aldás et al., 2011). Indeed, consumers really do need to trust online banking in order to manage their finances electronically (Hoehle et al, 2012). 
The operability of the website includes elements such as ease of browsing, attractive appearance, web design, or that the site conveys a sense of competency (Chau and Ngai, 2010). Moreover, websites must be consistent with consumers' technological knowledge and must also provide feedback to their users so that consumers will perceive that they are controlling what they are doing and where they are, at any given moment (Casaló et al., 2007).

Rapidity, understood as transaction speed (often referred to as response time), is an important factor in online banking. For example, Yoon (2010) finds this attribute to have a significant influence on user satisfaction of online banking in China. Furthermore, rapidity is one of the attributes that increases consumer preferences for online banking (Fozia, 2013).

A greater offer of products (loans, savings) has also been used in the analysis of perceptions of online banking. For example, online banking enables Internet auctions, which consist in granting the highest interest rates to the highest bidders for specific bank deposits. In addition, Internet banks are considered to offer a greater range of services than traditional banks (Torres and Vásquez-Párraga, 2005).

Reputation may be considered to be the result of the organisation's relational history with the context in which it functions (Casaló et al., 2007). Banks who operate through the Internet must manage their corporate image in order to distinguish themselves from the competition; with this being a key success factor (Liao et al., 2010).

In general, human or physical contact is a major element of any business service. However, this may be considered a limitation or weakness of online banking from a user perspective (Mansumitrchai and Al-Malkawi, 2011). A study of online banking carried out in Singapore found that $20 \%$ of those interviewed mentioned the lack of human interaction as a reason not to use it (Gerrard et al., 2006). Indeed, personal attention continues to be one of the competitive advantages of traditional banking (Torres and Vásquez-Párraga, 2005).

Finally, it is important to point out other aspects of online banking also perceived by consumers: profitability and commission charges. Both of these aspects focus on the economic nature of the service. Gerrard et al., (2008) group both commission charges and the interest obtained through deposits under the dimension "Prices". The profitability obtained by the online banking user generates greater satisfaction and client retention (Campbell and Frei, 2010). Although some studies show that online bank users believe that hidden commission charges are applied (Uppal, 2008).

\section{INSERT TABLE I}

\section{Netnography: concept, method, advantages and disadvantages}

Changes brought about by the Internet "bring about the need for research methods that enable developments to be determined in different online environments and the different virtual communities found therein, in terms of what, how, who, when, and where" (Turpo, 2008, p. 83). In view of this, a theoretical framework is needed and it is from this need that netnography emerges as a kind of online ethnography that provides a guide to adjusting participant observation techniques - planning field work, cultural 
intervention in this work, data collection, ensuring effective and quality interpretation of data, and ensuring the strictest adherence to ethical standards - in line with the singularities and contingencies of online community culture, through computermediated communication (Kozinets, 2002). In other words, netnography enables needs to be identified and understood on the basis of online consumer groups. Nevertheless, and as indicated by Fresno (2011, p. 66), "the decision as to whether the observation is participant or not in the online social context is one of the possibilities that netnography offers the researcher". Thus, non-participant observation requires presence, but not necessarily intervention, with the main advantage being the absence of alterations to or interferences with individuals' behaviour. The analysis is thus based on spontaneous opinions held by consumers. Having said this, the use of participant observation may or may not be combined with other tools such as, for example, online interviews using messages, thus facilitating the interactive nature of the Internet (Xun and Reynolds, 2010). For Hidalgo (2009), netnography is the branch of sociology used to analyse the free behaviour of individuals on the Internet. On the same lines, Fox and Roberts (1999) define netnography or cyber-ethnography as the sociology of virtual social spaces and online community interactions.

Another notable aspect of netnography research is that "people feel freer to organise their own narratives than to be bound to questionnaires with limited structures which restrict their direct experience" (Fresno, 2011, p. 76). In effect, "netnography” offers market researchers a window onto natural behaviours, as well as the search for information or discussions about products among consumers themselves (Kozinets, 2002, p. 62).

The netnographic method includes two phases (Turpo, 2008): data collection and human interpretation. The first phase begins with the search for forums, online communities and distribution lists related to the focus of the study. The selection criteria used can be based on the number of users or their level of activity (Kozinets, 2002). Other aspects to take into account are the variety of the content, the length of time it has been in circulation, and the existence of numerous accumulated messages, since the greater the number of interactions found among these components, the more they can be considered to be important sources of data (Dwyer, 2011).

After this, a decision should be made about how long the data collection phase will last, with this being sufficiently long enough to observe the interactions that occur between the members of the online community. Finally, messages containing useful information for the research are copied and filtered, organising them in accordance with related words, synonyms, concepts, and so on. In the second phase, the manual interpretation procedure, all the messages previously collected and filtered are read, classifying the comments according to a list of pre-established options. The research data needs to be interpreted responsibly in order to guarantee the validity of the results. Furthermore, we should also remember that the text recovered provides direct evidence of behaviour and also serves as evidence of what consumers know, feel or think (Scarabato, 2006). Finally, once a general impression has been gained about Internet users' opinions, an overall assessment is made, with a statistical interpretation of the data obtained. This can provide information about advantages and disadvantages, or the impact a product has on the market or on society, or on how it can be improved to achieve greater success in the future. 
The advantages offered by netnography, as opposed to other commercial research techniques, are (Kozinets 2002; and Xun and Reynolds, 2010): 1) rapidity and low cost; 2) collection of publicly available opinions which facilitates their analysis and tends to be substantial; 3) accessibility to a greater variety of interviewees; 4) higher quality of reflection and control of online opinions, since written responses can be refined before submitting; 5) obtaining of interesting and useful conclusions with relatively small numbers of messages, if these contain the descriptive richness required. Nevertheless, as with any new method, some inconveniences are also present: 1) doubts about user authenticity given that pseudonyms can be used; 2) it may be necessary to use other techniques to ensure the most precise analysis of the comments and opinions gathered; 3 ) the results obtained cannot be generalised to the whole population of consumers.

In summary, by tracing virtual communities, netnography provides the analyst with data on such communities, thereby constituting a method whereby knowledge can be gained about (online) consumers' opinions on any subject. In fact, “netnography has been used as a commercial research technique, using publicly available information to identify and understand needs and influences on online consumer decision-making” (Kozinets, 2002, p. 62). Table II shows how netnography has been applied to products as varied as coffee, the sale of tickets for music concerts, tourism, digital cameras, and fishing. A wide variety of different virtual spaces have been consulted, usually for a duration of months, and usually adopting a qualitative analysis of the information collected.

\section{INSERT TABLE II}

\section{Methodology}

In the study of user perceptions of online banking, normally techniques such as surveys, case studies or interviews have tended to be used (Hoehle et al, 2012). Nevertheless, these same authors indicate that researchers could learn much more about electronic banking by applying methodological approaches that have been under-utilised up to now, as is the case with netnography. Furthermore, netnography was used in this study since consumers are increasingly using online communities to access more objective information than that provided by companies (Kozinets, 2002, p.61). On the other hand, the data collection process is much more economical, short, simple and realistic (Braunsberger and Buckler, 2011). This study therefore represents a methodological contribution to the literature. In fact, the netnographic approach enables the existing perceptions of online consumer-bank relations to be identified, without the need to ask questions, as is the case with other data collection methods already used.

The field work began by searching for online communities with themes related to the exchange of information and the dissemination of positive and negative opinions among consumers about online commercial banking in Spain. Various websites were therefore found through the Google search engine, such as Dooyoo, Rankia, Ciao and Keob. Finally, the consumer online opinion portals Ciao and Rankia were selected for two reasons. Firstly, due to the number of visits they receive, since they occupy positions 24,857 and 14,014, respectively, on a worldwide level, and 908 and 211 on a national scale (Alexa, 2013). Therefore, two websites were used which enjoy high audience ratios and onto which information is entered via consumer comments. Secondly, this selection combines the use of a community that shares general opinions with another 
which is focused more specifically on financial issues. The general community Ciao includes over 5.8 million opinions on products and shops, while Rankia is the leading financial community in Spain, with over 10 million visits per month and over 100,000 registered users.

In the data collection process which took place from the end of 2010 to April 2013, messages were classified as being relevant or irrelevant for this study. In other words, messages that were not related to the theme of this study were excluded, as were, for example, those of ex-employees or those that could be considered to be self-promoting. Opinions about companies of the group that were not related to this study were also excluded. For example, a common case was that clients of ING National-Nederlanden, the Insurance company of the ING Group, confused it with ING Direct, the online banking brand of the ING Group. On the other hand, two criteria were considered in relation to the validity and reliability of the study. In the first place, to verify the data obtained, checks were made to ensure there were no contradictions between the opinion offered and the advantages or areas for improvement/disadvantages stated, or the worst points indicated in their reviews. As an example, if the comment highlighted poor customer service, it was rejected if customer service was then included in the section indicating advantages/the best. In second place, after careful reading, the information was entered into a word processor. Both authors of this study reviewed the same comments separately. After comparing this process, and in the case of any discrepancies, the messages were reviewed by a third independent researcher. Finally, the total number of valid messages obtained was 261. The analysis of these messages aimed to conserve the original texts from the forum in order to maintain the originality and spontaneity of the opinions, with this being considered one of the advantages of netnography. When deciding on the time period, the aim was to ensure homogeneity (during the period of the Spanish economic crisis), and a sufficiently wide range of years so that the results were not influenced by one-off promotions aimed at attracting new clients.

After this, when selecting the attributes and criteria, the bibliographical review discussed above regarding perceptions of online banking users was taken into account, as well as the frequency of citations they received in the opinions obtained. In this way, the list of attributes and criteria selected was: security, ease of use, website operability, range of products, customer service, profitability, and commission charges. Subsequently, the attributes were divided into two opposing categories (for example, easy or difficult to use) that enabled the positive and negative comments of each message to be included at different levels. It should be noted that this approach has already been used in other studies on attitudes towards online banking (Cai et al., 2008). On the other hand, the online banks included in this study were ING Direct, Openbank, i-Banesto, and Uno-e. They were selected given the fact that the existing comments found within online communities met the minimum number necessary to be able to carry out an analysis, and considering that together they cover almost $100 \%$ of the market according to the Spanish Banking Association.

Finally, two measurement methods exist which are used in practice to determine market positioning: composition or decomposition estimates. Composition estimates include the following phases (Dubois and Rovira, 1998): 1) selecting the brands that constitute the reference universe; 2) identifying the corresponding attributes; 3) defining the brand images in these attributes; and 4) constructing the representation space. In this case, in 
order to obtain the graphical representation of the perception universe of online banks, a correspondence analysis has been used. By contrast, the decomposition approach is based on the principle of proximity, which is to say on the similarity or lack of similarity between brands. To do this, an analysis based on Chi-square statistics can be used, which enables brands to be grouped together in categories (Bendixen, 1995). Using a table of attribute frequencies associated with brands, the phases to be followed are: 1) calculate the Chi-square statistic; 2) group two columns of the table, adding the frequencies of both values and recalculating the Chi-square statistic value, observing the change in the Chi-square value in relation to the original. Repeat this step for all the possible pairs of the columns; 3) select the pair of columns that present the smallest change of the Chi-square statistic as the first union of the classification tree, and take the distance in the union as the change in value of the Chi-square; 4) use the reduced matrix of the frequencies that emerge from the combination of the columns selected in the third step; 5) repeat steps two to four until the frequency matrix is reduced to one single column, and 6) create a dendrogram with the unions identified. Finally, it is worth noting that it is very useful to use both the composition and decomposition approaches (Dubois and Rovira, 1998) since, as indicated by Bendixen (1995: 572), "an important aspect of the interpretation of perceptual maps is the identification of brands that are perceived to be similar, i.e. that are associated with a set of similar attributes”.

Lastly, the quantitative analysis of the information collected, considering both approaches, was carried out using the CAR program (Lorenzo-Seva et al., 2009) for the factorial analysis of simple correspondences. On the other hand, a spreadsheet was used for the analysis based on Chi-square statistics.

\section{Results}

The Chi-square statistical analysis, which enables brands to be grouped together (Bendixen, 1995), and with a data matrix to the order of $14 \times 4$ (see Table III), helped to obtain dendrograms for attributes and banks (Figures 1 and 2, respectively), and the Chi-square distances in the unions in the case of online banks (Table IV). As a result of this, two types or groups of variables can be identified through the dendrogram of the attributes used to assess the online banks (Figure 1): the first includes practically all the positive aspects perceived by consumers as easy to use (3), the effective operability of the website (5), perceived security (1), wide range of products (7), good customer service (9), and low commission charges (14), together with two negative aspects: product range could be improved (8) and low profitability (12). On the other hand, the second group of attributes comprises a positive attribute for online bank users - high profitability (11) - alongside other negative aspects: customer attention could be improved (10), website operability could be improved (6) perceived as not secure (2), difficult to use (4) and high commission charges (13). Similarly, with the dendrogram of online banks in Spain (see Figure 2), two groups of companies can be distinguished: on the one hand, ING Direct (A) together with OpenBank (B), and, on the other, Uno-e (C) and i-Banesto (D).

Finally, it is important to point out that the choice, in both cases, of a solution with two groups is due to the fact that this facilitates the analysis of the data, as we can see in the following section. Moreover, as shown in Table IV, a sharp increase can be observed in the distance between unions 12 and 13 for the attributes (from 18.0 to 60.01) and, in unions 2 and 3 for online banks (21.48 to 81.39). Also, and as cited by Bendixen (1995), significant heterogeneity between the clusters can be identified by comparing the $\chi 2$ 
distance at the union with the largest eigenvalue of a Wishart matrix variate. Such values can be read from the tables for a given significance level (alpha). In this case, the critical distance is 31.5 .

\author{
INSERT TABLE III \\ INSERT TABLE IV \\ INSERT FIGURE 1 \\ INSERT FIGURE 2
}

On the other hand, applying a factorial analysis of simple correspondences to online banks in Spain, only axis 1 is considered, since its contribution to inertia is higher than $72 \%$ (see Table V). In effect, if the data was distributed completely at random, each eigenvalue would contribute the same inertia: in this case $100 / 3=33.3 \%$ Thus, any axis with an eigenvalue in excess of this proportion of the trace should be considered when deciding on the dimensionality of the solution (Bendixen, 1995). Furthermore, the inertia of this axis is sufficient for analysing results in social sciences, since it exceeds the minimum value of 50-60\% (Hair et al., 2006).

\title{
INSERT TABLE V
}

Table VI shows the coordinates and contributions of online Banks and the attributes for axis 1. In the first place, the online bank that stands out the most is i-Banesto (D), since it contributes $49.6 \%$ to the formation of the axis. ING Direct (A) has a similar representation. In second place, and in terms of attributes, it is worth noting that these are well represented in axis 1 , contributing strongly to the formation of the axis ${ }^{1}$ : easy to use (20.4\% of inertia), effective operability of the website (16.5\%), and perceived insecurity (8.8\%). Considering the situation of these attributes on the axis, it can be noted that convenience, both in terms of use (3) and operability of the website (5) is counter posed to perceptions of insecurity (2).

\section{INSERT TABLE VI}

\section{Discussion, limitations and future studies}

Bearing in mind the information obtained through the Chi-square statistical analysis, the positioning of online banking in Spain is characterised by the existence of two groups of competitors and two types of attributes. The dendrogram shown above (Figure 2) indicates that ING Direct (A) and OpenBank (B) are perceived as similar, as opposed to Uno-e (C) and i-Banesto (D). This result is also partially reflected in the factorial analysis of correspondences, in which ING Direct and i-Banesto are perceived as opposites in axis 1 . It is worth noting that ING Direct is the main online operator in

\footnotetext{
${ }^{1}$ If all the 14 attributes played an equal part in determining the axis, their contributions would be 100/14 $=7.1 \%$. Thus, any contribution in excess of $7.1 \%$ adds significant meaning to the axis being interpreted (Bendixen, 1995)
} 
Spain, with a market share of 70\%; and that OpenBank - the online bank of the Santander Group, which is the most successful financial entity in Spain - stands in second place after ING Direct, with a share of 18.5\% (Suárez, 2013). By contrast, the other group includes the two online banks with a smaller presence in the market. In other words, consumers perceive online banks as competitors according to their size. The specialised literature does in fact point out the impact that the size of the bank whether larger or smaller - has on their competitiveness within certain markets (Bikker and Haaf, 2000). The following comments also reflect this competitiveness in line with clients' perceptions of online banking: “I split my money between ING and OpenBank, even though my salary is paid into OpenBank. Recently, I've passed everything to ING due to a bad experience with Openbank"; "But apart from that ${ }^{2}$, it's really similar to use to ING, and therefore it's not bad'.

Observing the dendrogram of attributes related to perceptions of online banks in Spain, we can highlight two types or groups of variables. The first of these includes negative aspects, such as high commission charges (13), operability of the website (6), or customer services (10) could be improved, perception of insecurity (2), or difficult to use (4), alongside a positive attribute such as the obtaining of high profitability (11). In other words, some defects identified in the product can be compensated by high perceptions of other attributes; in this case higher profitability. The following client comment reflects this behaviour: "As negative points: security (neither a coordinates card nor a virtual keyboard are used), a fairly poor menu design (everything lumped together on one page) and commission charges for transfers. In terms of positive points, I'm happy with the good profitability of the products". This kind of behaviour is known as multi-attribute attitude models, compensatory models, or Fishbein models (LópezBonilla and López-Bonilla, 2011). A possible underlying hypothesis is that attitudes towards online banks are based on beliefs about their attributes, as well as the consequences obtained (high profitability).

In the other group of attributes, we find positive aspects, such as easy to use (3), effective operability of the web (5), perceived security (1), effective customer attention (9), low commission charges (14), alongside the negative attribute of low profitability (12). In this case, the compensatory model is also applicable, as illustrated in the following client comment: "They give low returns on savings, but I've never had any problems with them over the years". Profitability is therefore sacrificed in exchange for enjoying a good financial service online. It is worth pointing out that this group also includes an attribute - the range of products - which is simultaneously present in both its positive and negative components. Gerrard et al. (2006) highlight the low range of products to be one of the reasons for not being an online banking client. In view of this, the apparent contradiction noted above could be explained by the fact that a poor range of products is associated with a limited variety of financial products which, in turn, could be perceived as favourable if, despite this, the products offered satisfy the customers' needs. This is reflected in the following client comments: "They don't have a lot of variety in their products, but then again I don't use other products", or, "their stock exchange products are a bit limited, but I can manage my capital sufficiently". Although the portfolio of products may be limited, it provides them with sufficient options, thus linking client needs with the resources and offers provided by the company (Johnson and Selnes, 2004).

\footnotetext{
${ }^{2}$ Referring to OpenBank
} 
Considering the results of the factorial analysis of correspondences, it is worth highlighting that in the positioning of online banks in Spain, perceived insecurity is counter posed with convenience, both in terms of use and operability of the website. We can therefore observe once again the clash of negative and positive attributes perceived by online bank users in Spain, as indicated in the following comments: "It gives you a bit of a sense of insecurity... the website's ok, and the Iphone app is really good", or "the website's really good, it's very complete and fairly easy to use. A negative thing is security, since it only asks you for an electronic signature to do transfers, and doesn't give you a coordinates card or an SMS confirmation". This result provides empirical evidence of two of the dimensions proposed (easy to use and security) for the quality of online banking systems (Jun and Cai, 2001). Likewise, this is also partially confirmed since the axis used in the factorial analysis shows ING Direct to be opposed to iBanesto.

The conclusions obtained allow us to advance at least three key implications for the commercial management of the online financial sector. First, it would be interesting to obtain constant information on what is said about and what happens with online brands. The monitoring of online communities would thus help to detect trends, to discover the differential values that clients value most strongly in competitors, etc. Nevertheless, this procedure should be carried out in real time, since waiting for months, for example, could limit the usefulness of the information in the decision-making process. This would therefore enable comparisons to be made and the quick adaptation of marketing strategies.

Indeed, and in second place, this study presents a set of different opportunities for the online financial sector, in terms of improving their marketing management on the basis of their clients' online perceptions. For example, the application of commission charges alongside the provision of high profitability could be used to offer clients accounts where they have to pay commission charges in exchange for receiving higher yields. Or, conversely, since consumers tend to associate financial entities with low or no commission charges with low profitability, this could be positioned for individuals with low incomes who do not wish to pay for accounts, but are not interested in profitability either, since they do not have the financial means to make investments. In summary, by taking these kinds of existing relations between attributes into account, online banks could establish different ways of creating value for their clients.

Thirdly, linking positive aspects such as the effective operability of the website with perceptions of security could generate interesting synergies. For example, online banks could use the website to alert their clients to any possible frauds (Mansumitrchai and Al-Malkawi, 2011). Banks should also concentrate on the operability of their websites to make sure they are easy to use. These kinds of interactions confirm what has already been pointed out by authors such as Grabner-Kraüter and Faullant (2008), who highlight, for example, the existing relation between perceived security and ease of use.

Likewise, this study also makes an important contribution by highlighting the methodology used to determine online bank positioning. In effect, the information obtained using netnography represents a new way of researching online spaces which is currently undergoing a process of expansion. Netnography has therefore helped to obtain results on the positioning of online banks in Spain that are in keeping with 
previous studies, as discussed above. We can therefore conclude that the method does indeed work in this context and that netnograpy can provide a useful research tool to determine the positioning of online financial entities. Furthermore, the method used, which is to say the combined use of perceptual maps and dendrograms based on Chisquare statistics, helps to reduce subjective bias when interpreting the maps.

Having said that, the main limitation of this study is that it has not been possible to collect and verify the participants' socio-demographic characteristics (age, gender, place of residence, etc.). This aspect would have been particularly interesting since it has been observed that socio-demographic variables can influence decisions to use online banking (Tsai et al., 2013). It is clear, for example, that "Millenials" - individuals up to 34 years old - are more likely to express their opinions through messages. By contrast, people who are older than this, the designated "Baby Boom" generation (between 45 and 64), or those of 65 and upwards, either do not participate at all, or simply opt to read the messages published. It is also safe to say that opinions will vary by age as, for example, the younger the person the less interested they are in profitability, while the older they are the more interested in this aspect.

Finally, and taking into account the results discussed, it would also be interesting to conduct more in-depth research into the compensatory nature of profitability in relation to attributes such as the use or operability of the website, security, customer attention and commission charges. In order to do this, experiments could be carried out using techniques such as joint analysis. This would help to investigate the relative importance of the attributes indicated above, comparing them with different levels of profitability.

\section{References}

Adesina, A. A. and Ayo, Ch. (2010), “An Empirical Investigation of the Level of Users' Acceptance of E-Banking in Nigeria”, Journal of Internet Banking and Commerce, Vol. 15 No. 1, pp. 1-13.

Aladwani, A. (2001), "Online banking: a field study of drivers, development challenges, and expectations”, International Journal of Information Management, Vol. 21 No. 3, pp. 213-225.

Aldás, J., Lassala, C., Ruiz, C., and Sanz, S. (2011), “Análisis de los factores determinantes de la lealtad hacia los servicios bancarios online”, Cuadernos de Economía y Dirección de la Empresa, Vol. 14, pp. 26-39.

Alexa (2013), “Top Sites in Spain”, available at: www.alexa.com/siteinfo (accessed 5 April 2013).

Beaven, Z., and Laws, Ch. (2007), "Never Let Me Down Again: Loyal customer attitudes towards ticket distribution channels for live music events: a netnographic exploration of the US leg of the Depeche Mode 2005-2006 World Tour”, Managing Leisure, Vol. 12, pp. 120-142. 
Bendixen, M. T. (1995), “Compositional Perceptual Mapping Using Chi-squared Trees Analysis and Correspondence Analysis”, Journal of Marketing Management, Vol. 11, pp. 571-581.

Bikker, J., Haaf, K. (2000), Measures of competition and concentration in the banking industry: a review of the literature. Research Series Supervision 27, De Nederlandsche Bank.

Bin Omar, A., Sultan, N., Zaman, K., Bibi, N., Wajid, A., and Khan, K. (2011), "Customer Perception towards Online Banking Services: Empirical Evidence from Pakistan”, Journal of Internet Banking and Commerce, Vol. 16 No. 2, pp. 1-24.

Björk, P., and Kauppinen-Räisänen, H. (2012), "A netnographic examination of travelers' online discussions of risks”, Tourism Management Perspectives, Vol. 2-3, pp. 65-71.

Braunsberger, K., and Buckler, B. (2011), "What motivates consumers to participate in boycotts: Lessons from the ongoing Canadian seafood boycott”, Journal of Business Research, Vol. 64, pp. 96-102.

Cai, Y., Yang, Y., and Cude, B. (2008), "Inconsistencies in US consumers' attitudes toward and use of electronic banking: An empirical investigation”, Journal of Financial Services Marketing, Vol. 13 No. 2, pp. 150-163.

Calisir, F., and Gumussoy, C. A. (2008), "Internet banking versus other banking channels: Young consumers' view”, International Journal of Information Management, Vol. 28, pp. 215-221.

Campbell, D., and Frei, F. (2010), "Cost Structure, Customer Profitability, and Retention Implications of Self-Service Distribution Channels: Evidence from Customer Behavior in an Online Banking Channel”, Management Science, Vol. 56 No. 1, pp. 424.

Casaló, L., Flavián, C., and Guinalíu, M. (2007), “The role of security, privacy, usability and reputation in the development of online banking", Online Information Review, Vol. 31 No. 5, pp. 583-603.

Chau, V. S., and Ngai, L. W. L. C. (2010), "The youth market for internet banking services: perceptions, attitude and behaviour”, Journal of Services Marketing, Vol. 24 No. 1, pp. 42-60.

Christensen, H., Sastre, F., Serra, A., Llodrà, B., Sans, I., and Seda, C. (2008), Uso, necesidad e impacto de la oferta y la demanda de información turística multimedia de las Illes Balears en Internet. VII Congreso turismo y tecnologías de la información y las comunicaciones, Marbella (Málaga), 25-26 september. 
De Lassus, C., and Anido Freire, N., (2014), “Access to the luxury brand myth in popup stores: A netnographic and semiotic analysis”, Journal of Retailing and Consumer Services, Vol. 21 No. 1, pp. 61-68.

Dwivedi, M. (2009), “Online destination image of India: a consumer based perspective”, International Journal of Contemporary Hospitality Management, Vol. 21 No. 2, pp. 226-232.

Dwyer, P. (2011), “An approach to quantitatively measuring collaborative performance in online conversations”, Computers in Human Behavior, Vol. 27, pp. 1021-1032.

Dubois, B. and Rovira, A. (1998), Comportamiento del consumidor: comprendiendo al consumidor, Prentice Hall, Madrid,.

Alexa (2013), “Top Sites in Spain”, available at: www.alexa.com/siteinfo (accessed 5 April 2013).

España (2014), “Informe anual sobre el desarrollo de la Sociedad de la Información en España. Fundación Orange”, available at: http://fundacionorange.es/fundacionorange/analisis/eespana/e_espana14.html (accessed 5 December 2014).

Forrester (2014), "Forrester: Tablet Banking In Europe To Overtake Mobile Banking By 2016", available at: http://www.forrester.com/Forrester+Tablet+Banking+In+Europe+To+Overtake+Mobile +Banking+By+2016/-/E-PRE7024 (accessed 12 May 2014).

Fox, N., and Roberts, C. (1999), "GPs in cyberspace: the sociology of a 'virtual community”, The Sociological Review, Vol. 47 No. 4, pp. 643-671.

Fozia, Ms. (2013), “A Comparative Study of Customer Perception toward E-banking Services Provided By Selected Private and Public Sector Bank in India”, International Journal of Scientific and Research Publications, Vol. 3 No. 9, pp. 1-5.

Fresno, M. D. (2011), Netnografía, Editorial UOC, Barcelona.

Gerrard, P., Cunningham, B., and Devlin, J. F. (2006), "Why consumers are not using internet banking: a qualitative study”, Journal of Services Marketing, Vol. 20 No. 3, pp. 160-168.

Grabner-Kraüter, S., and Faullant, R. (2008), “Consumer acceptance of internet banking: the influence of internet trust”, International Journal of Bank Marketing, Vol. 26 No. 7, pp. 483-504.

Hair, J., Black, W., Babin, B., Anderson, R. and Tatham, R. (2006), Multivariate data analysis, Prentice-Hall International, Upper Saddle River, NJ. 
Hidalgo, F. (2009), “Netnografia”, available at: http://netnografia.blogspot.com.es (accessed 14 September 2012).

Hinson, R., Madichie, N., and Ibrahim, M. (2012), “A dialogic communications interrogation of the online brand dispositions of banks operating in Ghana", International Journal of Bank Marketing, Vol. 30 No. 7, pp. 508-526.

Hoehle, H., Scornavacca, E., and Huff, S. (2012), "Three decades of research on consumer adoption and utilization of electronic banking channels: A literature analysis”, Decision Support Systems, Vol. 54, pp. 122-132.

Johnson, M. J., and Selnes, F. (2004), "Customer portfolio management: Toward a dynamic theory of exchange relationships”, Journal of Marketing, Vol. 68 No. 2, pp. 117.

Jun, M. and Cai, S. (2001), "The key determinants of internet banking service quality: a content analysis”, The International Journal of Bank Marketing, Vol. 19 No. 7, pp. 276291.

Kozinets, R.V. (2002), “The field behind the screen: using netnography for marketing research in online communities”, Journal of Marketing Research, Vol. 39, pp. 61-72.

Kozinets, R.V. (2006), "Click to Connect: Netnography and Tribal Advertising”, Journal of Advertising Research, Vol. 46 No. 3, pp. 279-288.

Laforet, S., and Li, X. (2005), “Consumers' attitudes towards online and mobile banking in China”, International Journal of Bank Marketing, Vol. 23 No. 5, pp. 362380.

Laukkanen, T. (2007), "Internet vs mobile banking: comparing customer value perceptions”, Business Process Management Journal, Vol. 13 No. 6, pp. 788-797.

Liao, J., Cheng, R., and Wang, Z. (2010), Key Factors of Online Bank Brand Choice Intention. Basing on Mainland China Online Banks. 2010 IEEE International Conference on Industrial Engineering and Engineering Management, Macao (China), pp. 852-856.

Liao, Z., and Cheung, M. (2008), "Mesuring consumer satisfaction in online banking: A core framework”, Communications of the ACM, Vol. 51 No. 4, pp. 47-51.

López-Bonilla, L. M., and López-Bonilla, J. M. (2011), "Los modelos de adopción de tecnologías de la información desde el paradigma actitudinal”, Cad. EBAPE.BR, Vol. 9 No. 1, pp. 176-196.

Lorenzo-Seva, U., Van de Velden, M., and Kiers, H. A. (2009), “CAR: A MATLAB package to compute correspondence analysis with rotations”, Journal of Statistical Software, Vol. 31 No. 8, pp. 1-14. 
Loureiro, S., Rüdiger, H., and Rabino, S. (2014), "Intentions to use and recommend to others. An empirical study of online banking practices in Portugal and Austria”, Online Information Review, Vol. 38 No. 2, pp. 186-208.

Mäenpää, K., Kale, S., Kuusela, H., and Mesiranta, N. (2008), “Consumer perceptions of Internet banking in Finland: The moderating role of familiarity”, Journal of Retailing and Consumer Services, Vol. 15, pp. 266-276.

Mansumitrchai, S., and Al-Malkawi, H. (2011), "Factors Underlying the Adoption of Online Banking by Mexican Consumers”, International Journal of Business and Management, Vol. 6 No. 9, pp. 155-169.

Mavri, M., and Ioannou, G. (2006), “Consumers' perspectives on online banking services”, International Journal of Consumer Studies, Vol. 30 No. 6, pp. 552-560.

Nasri, W., and Charfeddine, L. (2012), "Factors affecting the adoption of Internet banking in Tunisia: An integration theory of acceptance model and theory of planned behavior”, Journal of High Technology Management Research, Vol. 23, pp. 1-14.

Ozdemir, S., Trott, P., and Hoecht, A. (2008), “Segmenting internet banking adopter and non-adopters in the Turkish retail banking sector”, International Journal of Bank Marketing, Vol. 26 No. 4, pp. 212-236.

Patsiotis, A., Hughes, T., and Webber, D. J. (2012), “Adopters and non-adopters of internet banking: a segmentation study”, International Journal of Bank Marketing, Vol. 30 No. 1, pp. 20-42.

Polatoglu, V. N., and Ekin, S. (2001), “An empirical investigation of the Turkish consumers' acceptance of Internet banking services”, International Journal of Bank Marketing, Vol. 19 No. 4, pp. 156-165.

Rageh, A., Melewar, T. C., and Woodside, A. (2013), "Using netnography research method to reveal the underlying dimensions of the customer/tourist experience”, Qualitative Market Research: An International Journal, Vol. 16 No. 2, pp. 126-149

Riffai, M. M. M. A., Grant, K., and Edgar, D. (2012), "Big TAM in Oman: Exploring the promise of on-line banking, its adoption by customers and the challenges of banking in Oman”, International Journal of Information Management, Vol. 32, pp. 239-250.

Scarabato, D. (2006), “Comunidades online como fonte de informação em marketing: reflexões sobre possibilidades e práticas”, Revista de Economía Política de las Tecnologías de la Información y Comunicación, Vol. VIII No. 3, pp. 26-41.

Suárez, R. (2013), “La banca electrónica en España”, Master’s thesis, University of Da Coruña, Spain, available at: http://ruc.udc.es/bitstream/2183/11690/2/SuarezGomez_Roman_TFM_2013.pdf 
Suki, N. M. (2010), “An Empirical Study of Factors Affecting the Internet Banking Adoption among Malaysian Consumers'”, Journal of Internet Banking and Commerce, Vol. 15 No. 2, pp. 1-11.

Torres, E., and Vásquez-Párraga, A. (2005), "Integrando los Beneficios para el Cliente de Servicios Bancarios: Banca Tradicional Versus Banca en Internet”, Panorama Socioeconómico, No jul-dic, pp. 8-21.

Tsai, C., Zhu, D., and Jang, Y. (2013), “A Study on the Consumer Adoption Behaviors of Internet Bank”, Journal of networks, Vol. 8 No. 12, pp. 2956-2963.

Turpo, O. W. (2008), La netnografía: método de investigación en Internet. Educar, Vol. 42, pp. 81-93.

Uppal, R. (2008), “Customer Perception of E-Banking Services of Indian Banks: Some Survey Evidence”, The ICFAI Journal of Bank Management, Vol. VII No. 1, pp. 63-78.

Waite, K., and Harrison, T. (2004), “Online banking information: what we want and what we get”, Qualitative Market Research: An International Journal, Vol. 7 No. 1, pp. 67-79.

Xun, J., and Reynolds, J. (2010), “Applying netnography to market research: The case of the online forum”, Journal of Targeting, Measurement and Analysis for Marketing, Vol. 18 No. 1, pp. 17-31.

Yoon, Ch. (2010), “Antecedents of customer satisfaction with online banking in China: The effects of experience”, Computers in Human Behavior, Vol. 26, pp. 1296-1304.

Yoon, H. S., and Barker Steege, L. M. (2013), “Development of a quantitative model of the impact of customers' personality and perceptions on Internet banking use", Computers in Human Behavior, Vol. 29, pp. 1133-1141. 